\title{
Phylogeography of the Neotropical catfish Pimelodus albicans (Siluriformes: Pimelodidae) from río de la Plata basin, South America, and conservation remarks
}

\author{
Julia Vergara $^{1}$, María de las Mercedes Azpelicueta ${ }^{2}$ and Graciela Garcia ${ }^{1}$
}

\begin{abstract}
Pimelodus albicans Valenciennes, 1840 (common name "moncholo" or "bagre blanco") is an endemic species of the family Pimelodidae in the río de la Plata basin. Phylogenetic approach based on cytochrome $b$ sequences was performed to test the existence of a unique evolutionary lineage in P. albicans and to discriminate populations units or subpopulations related to a migration behavior of this taxon in the río de la Plata basin. This study included 34 samples of $P$. albicans of different collecting sites in the río de la Plata estuary and in the río Arrecifes belonging to the río Paraná basin. Among 614 base pairs in the cytochrome b sequence data set, 203 were variable and 120 were phylogenetically informative sites in $P$. albicans. A total of twenty haplotypes, nucleotide diversity $(S)=0.032$ and haplotype diversity $=0.941$ were found. Tajima's test showed significant value $\mathrm{D}=-1.88(\mathrm{p}<0.05)$ rejecting the neutral mutation hypothesis for the $P$. albicans data set. All phylogenetic approaches showed that P. albicans included four monophyletic assemblages that were supported by high bootstrap and Bayesian posterior probability values. Minimum spanning network corroborated these groups for $P$. albicans haplotypes. High genetic structure was found in P. albicans by means of AMOVA analysis showing that the río Arrecifes samples constitute an isolated lineage. Moreover, the high value of genetic divergence (10\%) between the río de la Plata and the río Arrecifes populations could-suggest that $P$. albicans may be conformed by a sibling species complex. On the other hand, a degree of genetic structuring was detected among different sites of the río de la Plata. A partial isolation of the 760 site may suggest that $P$. albicans could migrates to different tributaries for reproduction, generating different schools of haplotypes which could mix in the río de la Plata estuary. The high nucleotide diversity found in the 765 site and the existence of gene flow with the remaining collecting sites would be concordant with the outlined hypothetic scenarios of the mixing populations in the middle of the río de la Plata estuary.
\end{abstract}

Pimelodus albicans Valenciennes, 1840 (popularmente conhecida como moncholo ou bagre branco) é uma espécie endêmica da família Pimelodidae na bacia do rio da Prata. Estudos filogeográficos baseados nas seqüências do citocromo b mitocondrial foram realizados para testar a existência de uma única linhagem evolutiva in $P$. albicans e para discriminar unidades populacionais relacionadas ao comportamento migratório desse táxon na bacia do rio da Prata. Um total de 34 amostras de $P$. albicans provenientes de diferentes lugares de coleta no estuário do rio da Prata e rio Arrecifes na bacia do rio Paraná foram analisados. Entre as 614 pares de bases do citocromo b no conjunto de dados, 203 deles variaram e 120 foram sítios filogeneticamente informativos para $P$. albicans. No presente estudo foi encontrado um total de vinte haplótipos, diversidade de nucleotídeos (S) $=0,032$ e diversidade de haplótipos $=0,941$. O teste de Tajima mostrou valores significativos $\mathrm{D}=-1,88(\mathrm{p}<0,05)$ rejeitando a hipótese de mutação neutra para os dados de $P$. albicans. Todas as análises filogenéticas mostraram que o clado $P$. albicans apresenta quatro grupos monofiléticos com um forte suporte estatístico e uma elevada probabilidade posterior Bayesiana. A rede de haplótipos para $P$. albicans mostrou uma forte estrutura desses quatro grupos. Uma grande estruturação genética foi observada em $P$. albicans nas análises de AMOVA mostrando que as amostras do rio Arrecifes constituem uma linhagem isolada. A alta divergência (10\%) encontrada entre as populações do rio da Prata e rio Arrecifes sugere que $P$. albicans pode constituir um complexo de espécies crípticas. Foi verificada também a ocorrência de estrutura genética na bacia do rio da Prata. A localidade 760 apareceu parcialmente isolada sugerindo que $P$. albicans migra para procriar em os afluentes do rio da Prata gerando diferentes cardumes de haplótipos que poderiam se misturar no estuário do rio da Prata. A alta diversidade nucleotídica encontrada na localidade 765 e a existência de fluxo gênico entre os demais sítios de coleta são concordantes com o cenário hipotético de existência de populações intercruzantes no meio do estuário do rio da Prata.

Key words: Population structure, Cytochrome b gene.

${ }^{1}$ Sección Genética Evolutiva, Facultad de Ciencias, Universidad de la República, Iguá 4225, CP 11400, Montevideo, Uruguay. ${ }^{2}$ División Zoología Vertebrados, Museo de La Plata, Paseo del Bosque, 1900 La Plata, Argentina. 


\section{Introduction}

Catfishes comprise 38 families and include more than 3000 species (Sullivan et al., 2006), representing an important component of the global fish fauna. Several authors concluded that catfishes constitute a monophyletic group of fishes (Fink \& Fink, 1981, 1986; de Pinna, 1998; Saitoh et al., 2003). The Siluriformes have a wide distribution, living in freshwater, estuarine and marine environments, from inland or coastal waters of all continents, excluded Antarctica where they have been present in the past (Grande \& Eastman, 1986). Probably, the high radiation of those fishes begun in the Late Cretaceous (de Muizon et al., 1983; Cione et al., 1985). Most members of the order inhabit freshwater environments and the highest catfish diversity occurs in the Neotropical Region. Neotropical catfishes are included in fifteen families: Ariidae, Astroblepidae, Aspredinidae, Auchenipteridae, Callichthyidae, Cetopsidae, Diplomystidae, Doradidae, Heptapteridae, Loricariidae, Nematogenyidae, Pimelodidae, Pseudopimelodidae, Scoloplacidae and Trichomycteridae. However, the relationships among catfish families are poorly understood. Three recent papers showed the difficulties to resolve interfamilial phylogenetic relationships with morphology information (Rodiles-Hernández et al., 2005) and molecular studies (Hardman, 2005; Sullivan et al., 2006).

Lundberg et al. (1991a, 1991b) showed that the traditional family Pimelodidae did not form a monophyletic group. This assemblage, including more than 300 species was separated in three monophyletic units (de Pinna, 1998) subsequently considered at family level, Pimelodidae (Lundberg \& Littmann, 2003), Heptapteridae (Bockman \& Guanzelli, 2003) and Pseudopimelodidae (Shibatta, 2003). Combining information of several authors and based on morphological characters de Pinna (1998) implemented a phylogenetic analyses, concluding that these families appeared to be more closely related to other catfishes than to each other (Fig.1). However, newly phylogenetic reconstruction based in molecular markers showed that these families conformed a monophyletic entity in which Heptapteridae clade appeared to be a sister group of the clade integrated by Pimelodidae and Pseudopimelodidae (Fig. 1, Hardman, 2005; Sullivan et al., 2006).

Molecular studies carried out during last years, involving Siluriformes, were focussed to resolve the complex phylogenetic relationships of catfishes at higher taxonomic levels, among or within families. However, more recent studies have characterized the catfish diversity at intrageneric level. A recently published paper about Mesoamerican populations of the genus Rhamdia using a strong molecular marker, the mitochondrial cytochrome $b$ gene, found high level of intrageneric diversity among populations of Rhamdia from Central and South America concluding that this taxon includes two major sibling species complex (Perdices et al., 2002).

The cytochrome $\mathrm{b}$ gene has proven to be an excellent molecular marker. It is widely used as a tool in molecular phylogeny of fishes, since this gene has both conservative and variable regions which contain signals that may be used in phylogeny at many different taxonomic levels (Kocher et al., 1989; Meyer et al., 1990; Cantatore et al., 1994; Martin \& Bermingham, 1998; Renesto et al., 2000; Garcia et al., 2000, 2002; So et al., 2006).

The río de la Plata basin is the second major one basin in South America. A family Pimelodidae member, Pimelodus albicans Valenciennes, 1840 (common name "moncholo" or "bagre blanco") is an endemic species of that basin, especially living in the río de la Plata and the lower areas of the rivers Paraná and Uruguay. This taxon seems to be a seasonal species of the assemblage living in the inner río de la Plata estuary (Jaureguizar et al., 2004). Adult fishes reach a maximum size of $65 \mathrm{~cm}$, occupying freshwater benthopelagic environments. This species represent a high value resource on the artisanal and commercial fisheries from estuarine and river areas. However, population dynamics and genetic structure are unknown. As other fishes from the río de la Plata basin, $P$. albicans carries out reproductive migrations from lower parts of rivers to the headwaters (Svertlij et al., 1998). The knowledge about spawning and breeding sites, movements and migrations of larvae and juveniles are almost completely unknown along its wide distribution.

Here we present a preliminary phylogeographic approach based on mitochondrial cytochrome b sequences to test the existence of a unique evolutionary lineage or a possible sibling species complex in $P$. albicans and to discriminate populations units or subpopulations related to migrations behaviour of this taxon in the río de la Plata basin. The knowledge of the dynamic and structure of $P$. albicans population are prerequisites for the design of appropriate resource management and conservation strategies.

\section{Material and Methods}

Samples and DNA extraction. The samples of $P$. albicans were obtained from specimens belonging to 5 collecting sites in the río de la Plata, between Argentina and Uruguay countries, during the travel of the BIP Dr. E. Holmberg cruiser, conducted by the FREPLATA Project (GEF, 2001). The voucher specimens of this Project were not preserved. Moreover, specimens from the río Arrecifes, an affluent of the Paraná river, in Argentina, were included (Fig. 2). In order to compare the level of the genetic divergence among sibling species complex several sequences of the genus Rhamdia were included as a part of the ingroup taxa: Rhamdia sp., $R$. cinerascens (AY036736), R. rogersi (AY036734), $R$. cabrerae (AY036726), R. nicaraguensis (AY036719), R. laticauda (AY036710, AY036704, AY036699, AF287456), R. wagneri (AY036695, AY036693, AY036678), and R. guatemalensis (AY036670, AY036667, AY036641,AY036634). Additionally in order to determinate the divergence at family level other species of the families Pimelodidae (Parapimelodus valenciennis, "Pimelodus" ornatus and Pimelodus pictus; AY458896) and Heptapteridae (Imparfinis sp., Pimelodella sp., and Pimelodella chagresi AY036751) were included. The outgroup analysis included cytochrome b sequences 
belonging to Diplomystes viedmensis and D. mesembrinus. Tissues and voucher specimens from the aforementioned Siluriformes genera were deposited in the Sección Genética Evolutiva Collection, Facultad de Ciencias, Montevideo, Uruguay (Catalog identification number is indicated in Table 1).

DNA was extracted from small pieces of liver and muscle tissues fixed in $\mathrm{EtOH}$, using proteinase $\mathrm{K}$ digestion, protein precipitation through sodium chloride and DNA total precipitation with ethanol (modified from Medrano et al., 1990).
Mitochondrial cytochrome b (cyt b) sequences. Amplification of approximately 800-bp fragment of cyt $b$ gene was performed by means of PCR experiments using GludgL and CB3H primers (Palumbi et al., 1991). The reaction occurs in 15PL, 1.5PL of core buffer $10 \mathrm{x}, 0.45 \mathrm{PL}$ of $\mathrm{MgCl}_{2}(50 \mathrm{mM}), 0.3 \mathrm{PL}$ of dNTPs (10mM), 0.25PL of each primer (10PM), 0,15 (5U/PL) of Taq DNA polimerase (Invitrogen $\left.{ }^{\mathrm{TM}}\right), 1.5 \mathrm{PL}$ of template DNA $(100-400 \mathrm{ng} / \mathrm{ml})$ and $10.6 \mathrm{PL}$ of $\mathrm{H}_{2} \mathrm{O}$. PCR cycle profile was as follow: $94^{\circ} \mathrm{C}$ for $45 \mathrm{~s}, 45^{\circ} \mathrm{C}$ for $45 \mathrm{~s}, 72^{\circ}$ for $1 \mathrm{~min}$; iterated during

\section{a}

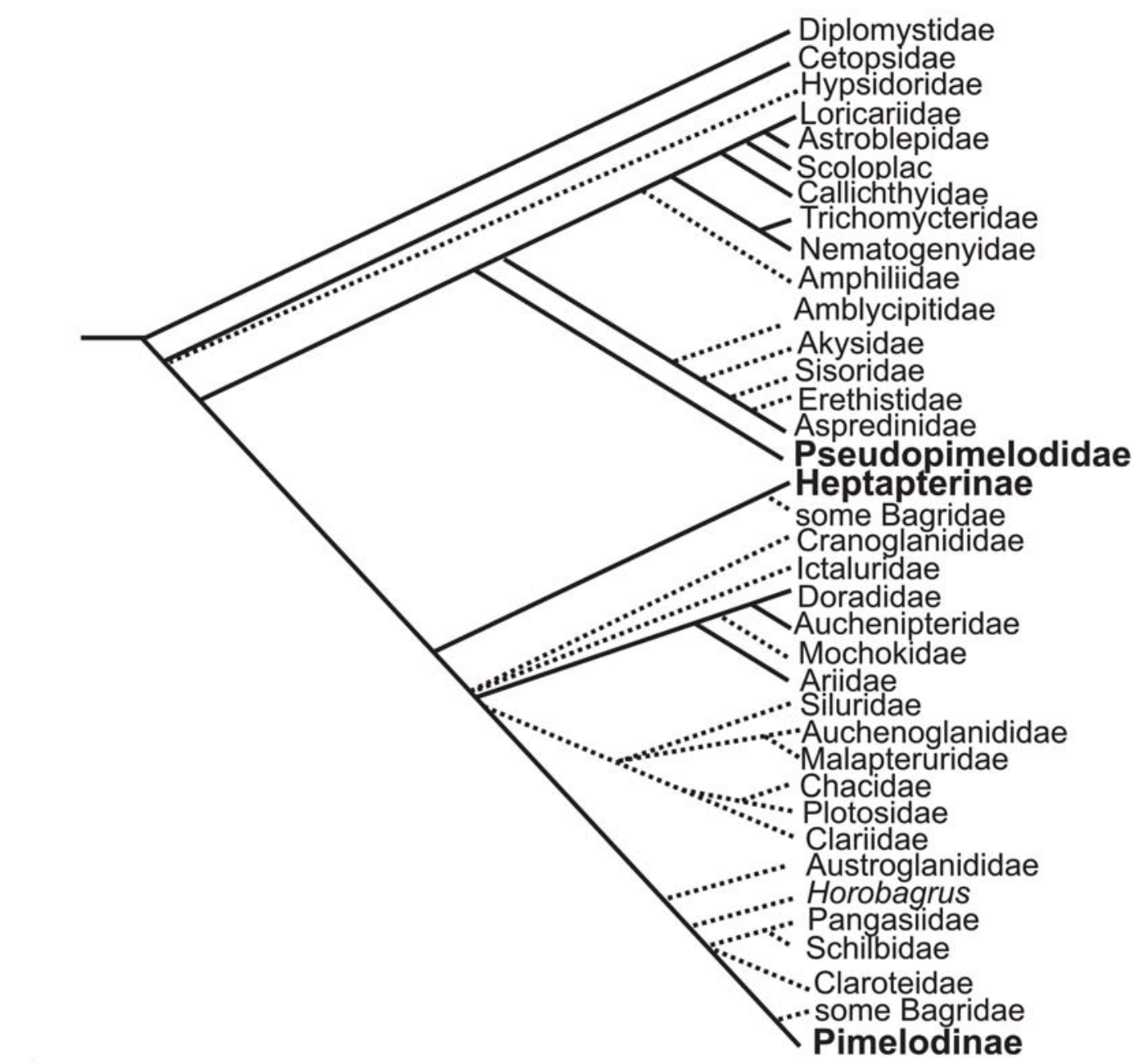

b

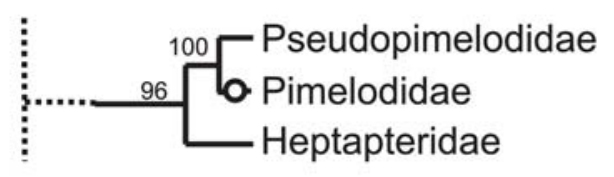

C

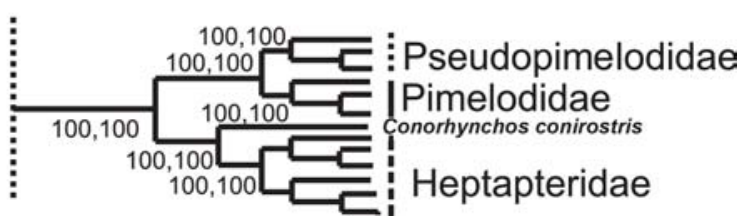

Fig. 1. Hypotheses of phylogenetic relationship among three Siluriformes families: Pimelodidae, Heptapteridae, Pseudopimelodidae. a- Cladogram presented by de Pinna (1998). b- Consensus tree among three most parsimonious topologies based on cyt b sequences modified from Hardman (2005). Numbers above nodes are posterior probabilities recovered by the Bayesian analysis for those clades common to both parsimony and likelihood topologies. Nodes with 0 failed to reject the null hypothesis of zero length, and are considered falsely resolved. c- Maximum parsimony analysis of ragl and rag2 sequences showing likelihood bootstrap values and Bayesian posterior probabilities (as \%) modified from Sullivan et al. (2006). 
Table 1. Specimens list included in this study. The corresponding number of laboratory catalog identification for each sample and cyt $\mathrm{b}$ haplotype in $P$. albicans are indicated. The number of specimens corresponding to each haplotype, their collecting sites GenBank Accession Numbers and Number of Voucher Specimens and Collection are included.

\begin{tabular}{|c|c|c|c|c|c|c|c|}
\hline Family & Species & cyt b haplotype & $\begin{array}{l}\text { Catalog } \\
\text { number }\end{array}$ & $\mathbf{n}$ & Collecting sites & $\begin{array}{l}\text { Accession umber } \\
\text { to GenBank }\end{array}$ & $\begin{array}{c}\text { Voucher Specimens } \\
\text { and Collection }\end{array}$ \\
\hline \multirow{37}{*}{ 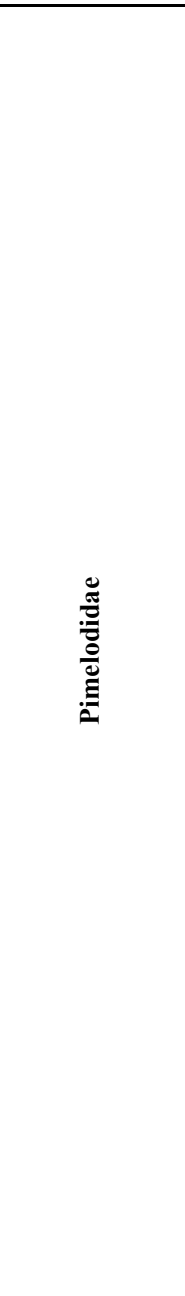 } & \multirow{34}{*}{ Pimelodus albicans } & \multirow{5}{*}{ Pa.hap1 } & P606 & & 756 & \multirow{5}{*}{ EF564718 } & \\
\hline & & & P619 & & 760 & & \\
\hline & & & P627 & 5 & 779 & & \\
\hline & & & P630 & & 765 & & \\
\hline & & & P631 & & 765 & & \\
\hline & & \multirow{3}{*}{ Pa.hap2 } & P609 & & 756 & \multirow{3}{*}{ EF564719 } & \\
\hline & & & P610 & 3 & 756 & & \\
\hline & & & P618 & & 760 & & \\
\hline & & Pa.hap3 & P607 & 1 & 756 & EF564720 & \\
\hline & & Pa.hap4 & P622 & 1 & 760 & EF564721 & \\
\hline & & Pa.hap5 & P614 & 1 & 771 & EF564722 & \\
\hline & & Pa.hap6 & P604 & 1 & 756 & EF564723 & \\
\hline & & Pa.hap7 & P616 & 1 & 771 & EF564724 & \\
\hline & & Pa.hap8 & P617 & 1 & 771 & EF564725 & \\
\hline & & \multirow{5}{*}{ Pa.hap9 } & $\mathrm{P} 605$ & & 756 & \multirow{5}{*}{ EF564726 } & \\
\hline & & & P613 & & 771 & & \\
\hline & & & P623 & 5 & 779 & & \\
\hline & & & P624 & & 779 & & \\
\hline & & & P625 & & 779 & & \\
\hline & & Pa.hap10 & P633 & 1 & 756 & EF564727 & \\
\hline & & Pa.hap11 & P629 & 1 & 765 & EF564728 & \\
\hline & & Pa.hap12 & P628 & 1 & 765 & EF564729 & \\
\hline & & \multirow{5}{*}{ Pa.hap13 } & $\mathrm{P} 621$ & & 760 & \multirow{5}{*}{ EF564730 } & \\
\hline & & & P632 & & 765 & & \\
\hline & & & P634 & 5 & 765 & & \\
\hline & & & P636 & & 760 & & \\
\hline & & & P637 & & 760 & & \\
\hline & & Pa.hap14 & P635 & 1 & 760 & EF564731 & \\
\hline & & Pa.hap15 & P611 & 1 & 760 & EF564732 & \\
\hline & & Pa.hap16 & P612 & 1 & 760 & EF564733 & \\
\hline & & Pa.hap17 & P294 & 1 & & EF564734 & \\
\hline & & Pa.hap18 & P296 & 1 & Argentına, Buenos & EF564735 & AI 219, Coll. Sergio \\
\hline & & Pa.hap19 & P293 & 1 & Aires, río Arrecifes, & EF564736 & Bogan \\
\hline & & Pa.hap20 & P295 & 1 & Jul 2005 & EF564737 & \\
\hline & \multirow{2}{*}{$\begin{array}{l}\text { Parapimelodus } \\
\text { valenciennis }\end{array}$} & & P96 & 1 & \multirow[t]{2}{*}{ Uruguay } & EF564738 & $\begin{array}{l}\text { P96, Coll. Sección } \\
\text { Genética Evolutiva }\end{array}$ \\
\hline & & & P97 & 1 & & EF564739 & $\begin{array}{l}\text { P97, Coll. Sección } \\
\text { Genética Evolutiva }\end{array}$ \\
\hline & $\begin{array}{l}\text { "Pimelodus" } \\
\text { ornatus }\end{array}$ & & P279 & 1 & $\begin{array}{c}\text { Argentina, Misiones, río } \\
\text { Paraná, Posadas }\end{array}$ & EF564741 & $\begin{array}{c}\text { uncat., Coll. M. } \\
\text { Azpelicueta }\end{array}$ \\
\hline \multirow{3}{*}{ Heptapteridae } & Pimelodella sp. & & P116 & 1 & Uruguay & EF564740 & $\begin{array}{l}\text { P116, Coll. Sección } \\
\text { Genética Evolutiva }\end{array}$ \\
\hline & Imparfinis sp. & & P283 & 1 & $\begin{array}{l}\text { Argentina, río Iguazú } \\
\text { basin, Feb } 2002\end{array}$ & EF564742 & $\begin{array}{l}\text { AI 211, Coll. M. } \\
\text { Moreno }\end{array}$ \\
\hline & Rhamdia sp. & & P284 & 1 & $\begin{array}{l}\text { Argentina, Misiones, } \\
\text { Cuñapirú Oct } 2004\end{array}$ & EF564743 & $\begin{array}{l}\text { uncat., Coll. M. } \\
\text { Azpelicueta }\end{array}$ \\
\hline \multirow[t]{2}{*}{ Diplomystidae } & $\begin{array}{l}\text { Diplomystes } \\
\text { viedmensis }\end{array}$ & & P280 & 1 & $\begin{array}{c}\text { Argentina, río Negro, } \\
\text { lago Moreno Este, } \\
\text { Mar } 2000\end{array}$ & EF564744 & $\begin{array}{l}\text { unact., Coll. Liliana } \\
\text { Semenas }\end{array}$ \\
\hline & $\begin{array}{l}\text { Diplomystes } \\
\text { mesembrinus }\end{array}$ & & P282 & 1 & Argentina & EF564745 & $\begin{array}{c}\text { Cenpat 1999/1-1, A. E. } \\
\text { Gosztonyi }\end{array}$ \\
\hline
\end{tabular}

38 cycles. The resulting products were purified for direct sequencing with the kit: CONCERT ${ }^{\mathrm{TM}}$ Rapid PCR Purification System (Gibcoâ). Sequences were obtained using a PerkinElmer ABI Prisma 337 automatic sequencer in the Centro Técnico de Análisis Genéticos (CTAG) from Facultad de Ciencias, Universidad de la República, Montevideo, Uruguay.

The final sequence data set resulted by reconciling chromatograms for the light and heavy DNA strands. Sequence alignment was performed using CLUSTAL X program, version 1.8 (Thompson et al., 1997).
Statistical analyses, DNA polymorphism. Nucleotide composition and substitution patterns were calculated using MEGA (Kumar et al., 2004) and DnaSP4 (Rozas et al., 2003) software packages. The corrected estimation of pairwise sequence divergence was obtained using Kimura twoparameter algorithm (K2P, Kimura, 1980) implemented with MEGA software. DNA polymorphism was measured calculating the proportion of segregating sites (S), the haplotype diversity (Nei, 1987: 179) and the nucleotide diversity S(Nei, 1987: 257) using ARLEQUIN (Excoffier et al., 
2005) and DNASP4 (Rozas et al., 2003) software packages.

Tajima's test (Tajima, 1989) was performed to estimate the significant excess of low-frequency haplotypes in order to evaluate the hypothesis of population expansion for all data set using the DnaSP4 (Rozas et al., 2003).

ARLEQUIN 3.01 software package (Excoffier et al., 2005) was used to compute Tajima's D (Tajima, 1989) and Fu's Fs (Fu, 1997) neutrality tests grouping río de la Plata and río Arrecifes samples separately.

Phylogenetic Analyses. In order to access to the phylogeographic association among mitochondrial haplotypes, different methods of phylogenetic reconstruction using PAUP*4.0b8 (Swofford, 1998) were performed: maximum-parsimony (MP), neighbour-joining (NJ) and maximum-likelihood (ML). An equally weighted maximum-parsimony analysis was carried out through heuristic search (MULPARS option, stepwise addition, tree-bisectionreconnection [TBR] branch swapping, 100 replications). A strict consensus between rival trees was computed to found equally parsimonious topologies. Distance trees were generated under Hasenawa, Kishino \& Yano model (1985) which considers differences among transversion and transition substitutions and among base frequencies. The phylogenetic reconstruction was subjected to the neighbourjoining method (Saitou \& Nei, 1987). The degree of confidence assigned to nodes in the trees was assessed by bootstrapping with 500 replicates for both methods (MP and NJ). ML analysis was based on the optimal model of nucleotide substitution through the hierarchical likelihood ratio test (hLRTS) and additionally based on the Akaike Information Criterion (AIC); both analyses were implemented in the Modeltest v3.7 (Posada \& Crandall, 1998). General time re-

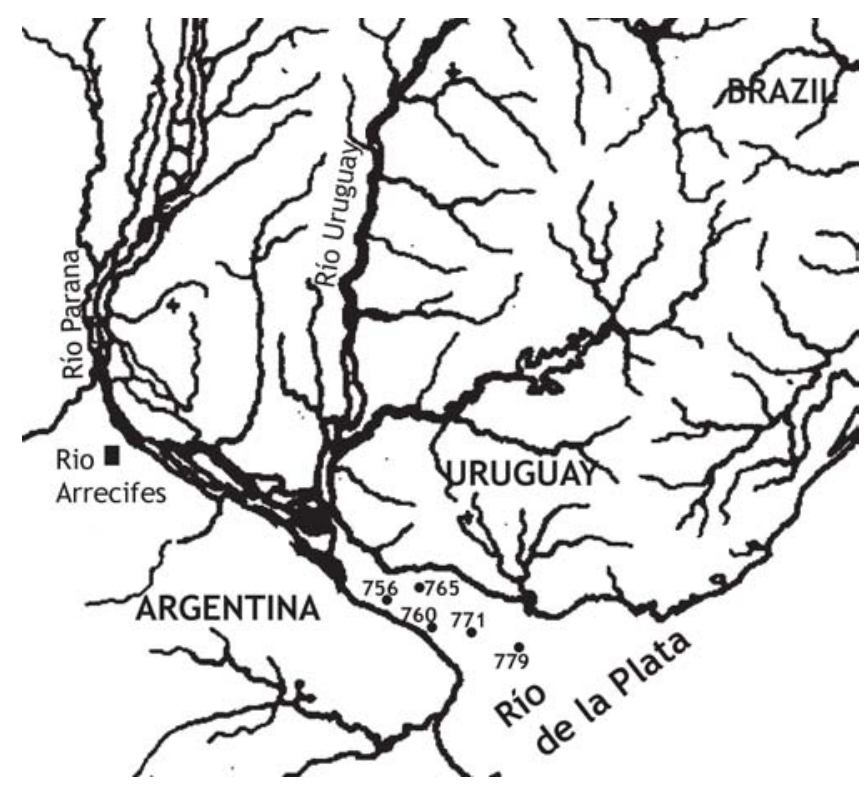

Fig. 2. Map showing the collecting sites of Pimelodus albicans. The square represents the río Arrecifes, the remaining localities are indicated in the río de la Plata. versible model whit gamma distribution $(\mathrm{GTR}+\mathrm{G})$ resulted to be the best model for nucleotide substitution for these cyt $b$ sequences. The ML tree topologies were inferred using that model. All trees were rooted by outgroup criterion using the Diplomystidae taxa. Bayesian inference (Rannnala \& Yang, 1996) was implemented to access to the posterior probability of ML clades using Mr. Bayes 3.1 (Ronquist \& Huelsenbeck, 2003).

Analysis of Molecular Variance and Minimum Spanning Network. The hierarchical partitions of the genetic variance components in the data set of $P$. albicans were assessed through the Analysis of Molecular Variance (AMOVA) developed by Excoffier et al. (1992). The Euclidean metric of Excoffier et al. (1992) was used to construct the matrix of pairwise distances. Each haplotypes was assigned to their corresponding collecting site. The genetic variation was partitioned into three components: among groups, among populations (collecting sites) within groups and among individuals, disregarding either their original populations or their groups.

The relationships among the cyt b haplotypes were inferred through a minimum spanning tree based on the mean number of pairwise differences between haplotypes using the ARLEQUIN 3.01 software package (Excoffier et al., 2005).

Population structure was measured assuming the infinite mutation model (Kimura \& Crow, 1964) and calculating the $\mathrm{F}_{\mathrm{ST}}$ (Slatkin, 1991) for the whole population. Pairwise estimates of $\mathrm{F}_{\mathrm{ST}}$ were calculated using ARLEQUIN 3.01 (Excoffier et al., $2005)$ to generate pairwise estimates of gene flow with the following formula: $\mathrm{N}_{\mathrm{f}} \mathrm{m} \mid 1 / 2\left[\left(1 / \mathrm{F}_{\mathrm{ST}}\right)-1\right]$ (Wright, 1951).

\section{Results}

Sequence Analysis and DNA Polymorphism. Present data set included approximately $614 \mathrm{bp}$ of mitochondrial cyt $b$ sequences belonging to $P$. albicans and other genera of the family Pimelodidae, Heptapteridae, and Diplomystidae. All sequences of $P$. albicans $(\mathrm{N}=34)$ as well as those of other pimelodids $(\mathrm{N}=3)$, heptapterids $(\mathrm{N}=3)$, and diplomystids $(\mathrm{N}=2)$ constitute new data set from catfishes (GeneBank accessions numbers are shown in Table 1).

Table 2 shows the pairwise genetic corrected distance values among the ingroup and the outgroup taxa using Kimura two-parameter model (K2P). The average nucleotide divergence between outgroup and ingroup was $17.5 \%$.

The $P$. albicans nucleotide sequences analysis showed 203 variables and 120 phylogenetically informative sites. Base frequencies were $27.7 \% \mathrm{~A}, 27.7 \% \mathrm{~T}, 28.0 \% \mathrm{C}$, and $16.5 \% \mathrm{G}$. Similar values were observed in other Siluriformes (Peng et al., 2004; Shimabukuro-Dias et al., 2004). The average ratio of Ts:Tv (R) for cyt b sequence within $P$. albicans samples was 0.7 . No indels of nucleotide sequences were detected. The obtained data set resulted in 204 amino acids: 111 were variables and 59 of them were phylogenetically informative sites.

Twenty haplotypes, nucleotide diversity $(S)=0.032$ and 
haplotype diversity $=0.941$ were found in the $P$. albicans data set. Table 3 shows nucleotide diversity $(S)$ for each collecting site. The average of genetic divergence among samples from all collecting sites was $5.7 \%$ and the pairwise genetic distances between them are presented in Table 4. Remarkably, río Arrecifes samples were separated by $10 \%$ of the genetic distance from all other localities. Additionally, the locality 760 was the most distant (2\%) among all other remaining sites in the río de la Plata.

The Tajima's test has showed significative value $\mathrm{D}=-1.88$ $(p<0.05)$ which rejected the neutral mutation hypothesis for all these data set. Additionally, Tajima's D and Fu's Fs tests were not significant considering río Arrecifes and río de la Plata like separated sites (Table 3).

Phylogenetic analyses. All the phylogenetic approaches yielded to the same tree topology and showed two major clades: the first one includes the monophyletic family Heptapteridae and several members of the family Pimelodidae and the second one corresponds to P. albicans haplotypes. Nonetheless, each of them received different bootstrap support in MP, but they were well resolved in the ML tree topology and through Bayesian Inference (Fig. 3). Remarkably, the genus Pimelodus appears as a paraphyletic taxon and $P$. ornatus collapsed in a basal position of the tree.

Pimelodus albicans forms a monophyletic group showing high bootstrap support and bayesian posterior probability (Fig. 3). In both analyses P. albicans included four monophyletic assemblages supported by high bootstrap and Bayesian posterior probability values. The first clade comprised all río Arrecifes samples (1 in Fig. 3). The other clades were composed by río de la Plata samples as follows: the second clade ( 2 in Fig. 3 ) included samples from collecting site 771, the third clade ( 3 in Fig. 3 ) was predominantly integrated by samples from 760 and 765 sites, and the fourth clade (4 in Fig. 3) included a mix of individuals from four collecting sites $(756,765,771$, and 779). The remaining $P$. albicans haplotypes $(1,2,3,4,5,6,10$ and 11) collapsed in a basal polytomy joining the above mentioned clades. The first and second clades of $P$. albicans were the most divergent (see Figs. 3-4).

AMOVA analyses, Haplotype Network and Mantel test. To analyse the hierarchical partition of the genetic variation, four different hypotheses were tested: 1) all haplotypes of $P$. albicans considering their corresponding collecting sites as population were included in a single group; 2) the haplotypes included in their corresponding collecting sites were distributed in two groups: one of them including the río de la Plata samples and the other one with specimens of the río Arrecifes; 3) the haplotypes were distributed in five groups according to present phylogeographic results; 4) the haplotypes were separated in three groups corresponding to río Arrecifes, locality 760 from río de la Plata and the remaining río de la Plata samples.

Table 5 shows the results of the hierarchical partition of the variance components. This analysis revealed that under five groups hypothesis the percentage of genetic variation $(80 \%)$ among groups was higher than other alternative hypotheses. Moreover, the fixation index () ${ }_{\text {st }}$ ) was 0.79 . These values were similar under the hypotheses 2 and 3.

Minimum spanning network based on cyt $b$ sequences (Fig. 4) showed a strong structure among haplotypes of $P$. albicans conforming four groups. Haplotype 1 was the most

Table 2. Pairwise corrected genetic distances among Siluriformes taxa (below diagonal) and values of the corresponding standard error computed by bootstrap ( 500 replicates) (above diagonal).

\begin{tabular}{|c|c|c|c|c|c|c|c|c|}
\hline & 1 & 2 & 3 & 4 & 5 & 6 & 7 & 8 \\
\hline 1 Rhamdia $\mathrm{sp}$. & & {$[0.013]$} & {$[0.029]$} & {$[0.021]$} & {$[0.020]$} & {$[0.022]$} & {$[0.030]$} & {$[0.025]$} \\
\hline 2 Pimelodella sp. & 0.061 & & {$[0.030]$} & {$[0.025]$} & {$[0.024]$} & {$[0.022]$} & {$[0.032]$} & {$[0.027]$} \\
\hline 3 Imparfinis sp. & 0.269 & 0.276 & & {$[0.027]$} & {$[0.027]$} & {$[0.027]$} & {$[0.041]$} & {$[0.031]$} \\
\hline 4 Pimelodus albicans & 0.170 & 0.197 & 0.254 & & {$[0.013]$} & {$[0.019]$} & {$[0.028]$} & {$[0.017]$} \\
\hline 5 Parapimelodus valenciennis & 0.154 & 0.172 & 0.252 & 0.059 & & {$[0.017]$} & {$[0.028]$} & {$[0.019]$} \\
\hline 6 Pimelodus pictus & 0.176 & 0.155 & 0.248 & 0.125 & 0.091 & & {$[0.031]$} & {$[0.025]$} \\
\hline 7 Diplomystes spp. & 0.261 & 0.262 & 0.411 & 0.223 & 0.206 & 0.242 & & {$[0.030]$} \\
\hline 8 Pimelodus ornatus & 0.222 & 0.219 & 0.297 & 0.103 & 0.121 & 0.180 & 0.224 & \\
\hline
\end{tabular}

Table 3. Nucleotide diversity (S) for Pimelodus albicans for each locality from the río de la Plata and río Arrecifes. $\mathrm{D}=$ Neutrality test (Tajima, 1989). Fs $=$ Neutrality test $(\mathrm{Fu}, 1997)$ corresponding to río de la Plata and río Arrecifes sites.

\begin{tabular}{ccccc}
\hline \multicolumn{2}{c}{ Locality } & $\pi$ & Fu's F & Tajima's D \\
\hline \multirow{2}{*}{ río de } & 756 & $0.083056+/-0.050820$ & & \\
la & 760 & $0.139671+/-0.080120$ & 0.33330 & 0.61823 \\
Plata & 771 & $0.187879+/-0.112971$ & $(\mathrm{p}>0.05)$ & $(\mathrm{p}>0.05)$ \\
& 779 & $0.042017+/-0.030791$ & & \\
\multicolumn{2}{c}{ río Arrecifes } & $0.173516+/-0.118929$ & $\begin{array}{l}0.60661 \\
(\mathrm{p}>0.05)\end{array}$ & $\begin{array}{c}0.57082 \\
(\mathrm{p}>0.05)\end{array}$ \\
\hline
\end{tabular}

Table 4. Pairwise corrected genetic distances for Pimelodus albicans among all the collecting sites (below diagonal) and values of the corresponding standard error computation by bootstrap (500 replicates) (above diagonal).

\begin{tabular}{lllllll}
\hline & 756 & 760 & 765 & 779 & 771 & $\begin{array}{l}\text { Río } \\
\text { Arr. }\end{array}$ \\
\hline 756 & & $(0.005)$ & $(0.003)$ & $(0.003)$ & $(0.004)$ & $(0.015)$ \\
760 & 0.025 & & $(0.004)$ & $(0.005)$ & $(0.005)$ & $(0.015)$ \\
765 & 0.016 & 0.022 & & $(0.003)$ & $(0.004)$ & $(0.015)$ \\
779 & 0.010 & 0.023 & 0.012 & & $(0.004)$ & $(0.015)$ \\
771 & 0.016 & 0.029 & 0.019 & 0.012 & & $(0.015)$ \\
río Arrecifes & 0.103 & 0.116 & 0.106 & 0.100 & 0.106 & \\
\hline
\end{tabular}


frequent and central in the network analysis, representing perhaps the most ancestral one among the río de la Plata samples.

The pairwise $\mathrm{F}_{\mathrm{ST}}$ and $\mathrm{Nm}$ values among collecting sites were presented in Table 6. Noticed, the samples from río Arrecifes presented the highest pairwise $\mathrm{F}_{\mathrm{ST}}$ values $(>0.7)$ and they showed absence of gene flow from all other collecting sites. In the río de la Plata, the 760 collecting site only shows genetic exchange with locality 765 and it appeared to be an isolated site from the rest. Moreover, 779 and 756 sites represent the most distant ones in the río de la Plata, showing absence of genetic exchange.
Discussion

High level of genetic diversity in the family Pimelodidae. In the present work, the genetic divergence among species of the family Pimelodidae ranged from $6 \%$ to $12 \%$. In fact, the family Pimelodidae and the genus Pimelodus were paraphyletic (Fig. 3). Even though our analyses included a very limited number of taxa compared with previous molecular phylogenetic analyses in Siluriformes, our present data showed that two members of the family Pimelodidae resulted sister groups of the monophyletic Heptapteridae family

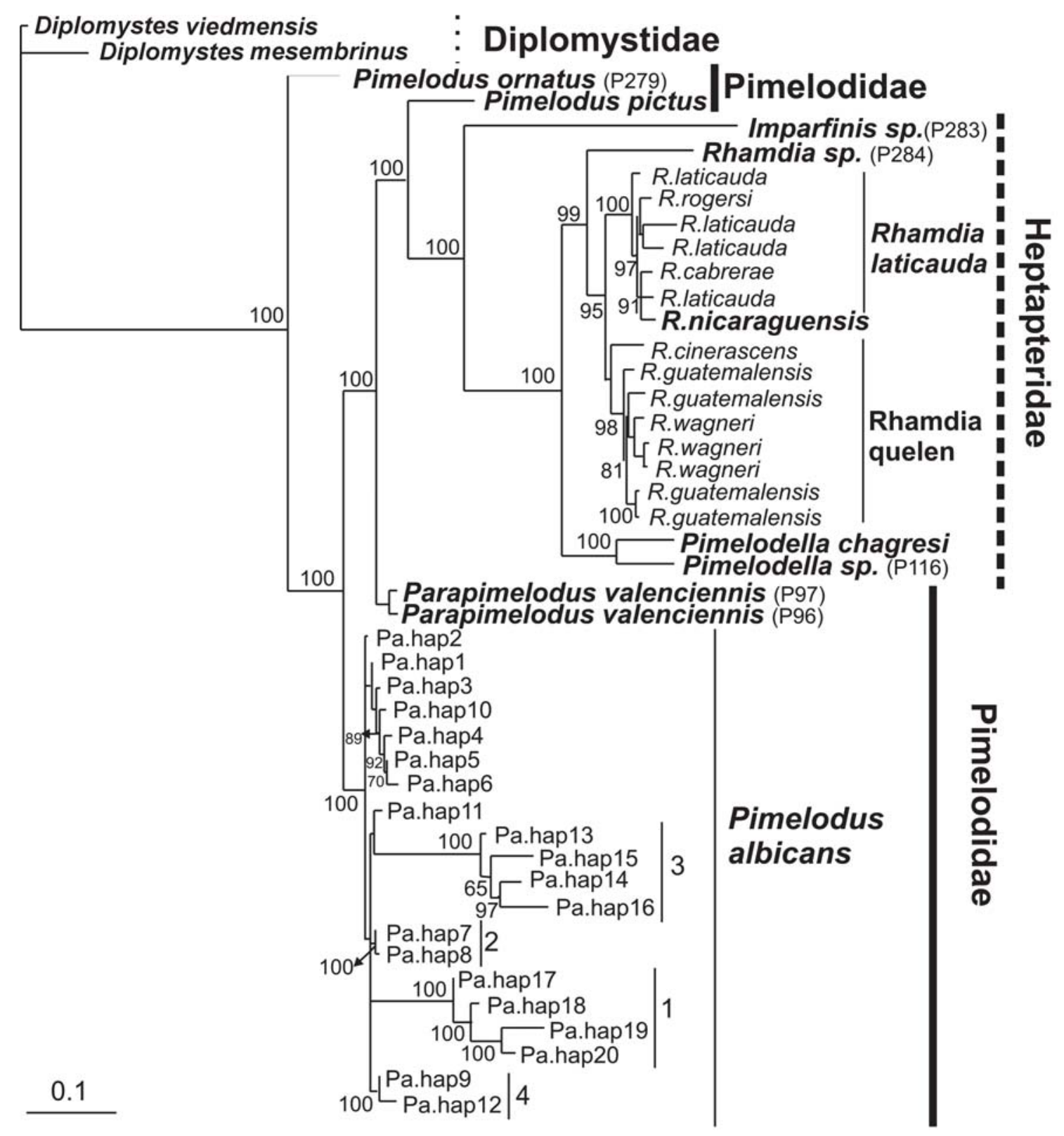

Fig. 3. Maximum likelihood tree based on GTR $+\mathrm{G}$ model, showing Bayesian support values in the nodes. Pimelodidae family appears basal and paraphyletic whereas P. albicans conforms as a monophyletic assemblage. Pimelodus albicans clade shows four monophyletic groups with strong clade support. 
Table 5. Hierarchical partition of the variance components for Pimelodus albicans haplotypes under four different hypotheses: 1) a single group; 2) two groups including the río de la Plata samples and the río Arrecifes samples; 3 ) five groups according to present phylogeographic results; 4) three groups from río Arrecifes, locality 760, and remaining localities in the río de la Plata.

\begin{tabular}{|c|c|c|c|c|c|c|}
\hline$\overline{\text { Hyp }}$ & Source of variation & $\begin{array}{l}\text { Degrees of } \\
\text { freedom }\end{array}$ & Sum of squares & $\begin{array}{l}\text { Variance } \\
\text { components }\end{array}$ & $\begin{array}{l}\text { Percentage of } \\
\text { variation }\end{array}$ & $\Phi$ statistics \\
\hline \multirow[t]{3}{*}{1} & Among groups & 5 & 149.663 & $4.72332 \mathrm{Va}$ & 55.68 & - \\
\hline & Among population within groups & - & - & - & - & - \\
\hline & Within populations & 28 & 105.278 & $3.75992 \mathrm{Vb}$ & 44.32 & $\Phi_{\mathrm{ST}}=0.55678$ \\
\hline \multirow[t]{3}{*}{2} & Among groups & 1 & 106.225 & $13.77550 \mathrm{Va}$ & 73.47 & $\Phi_{\mathrm{CT}}=0.73473$ \\
\hline & Among population within groups & 4 & 43.439 & $1.21364 \mathrm{Vb}$ & 6.47 & $\Phi_{\mathrm{CS}}=0.24402$ \\
\hline & Within populations & 28 & 102.278 & $3.75992 \mathrm{Vc}$ & 20.05 & $\Phi_{\mathrm{ST}}=0.79946$ \\
\hline \multirow[t]{3}{*}{3} & Among groups & 4 & 204.233 & $8.16359 \mathrm{Va}$ & 83.79 & $\Phi_{\mathrm{CT}}=0.83789$ \\
\hline & Among population within groups & 8 & 8.958 & $-0.40861 \mathrm{Vb}$ & -4.19 & $\Phi_{\mathrm{CS}}=-0.25870$ \\
\hline & Within populations & 21 & 41.750 & $1.98810 \mathrm{Vc}$ & 20.41 & $\Phi_{\mathrm{ST}}=0.79595$ \\
\hline \multirow[t]{3}{*}{4} & Among groups & 2 & 134.294 & $6.79562 \mathrm{Va}$ & 62.80 & $\Phi_{\mathrm{CT}}=0.62803$ \\
\hline & Among population within groups & 3 & 15.369 & $0.26505 \mathrm{Vb}$ & 2.45 & $\Phi_{\mathrm{CS}}=0.06585$ \\
\hline & Within populations & 28 & 105.278 & $3.75992 \mathrm{Vc}$ & 34.75 & $\Phi_{\mathrm{ST}}=0.65252$ \\
\hline
\end{tabular}

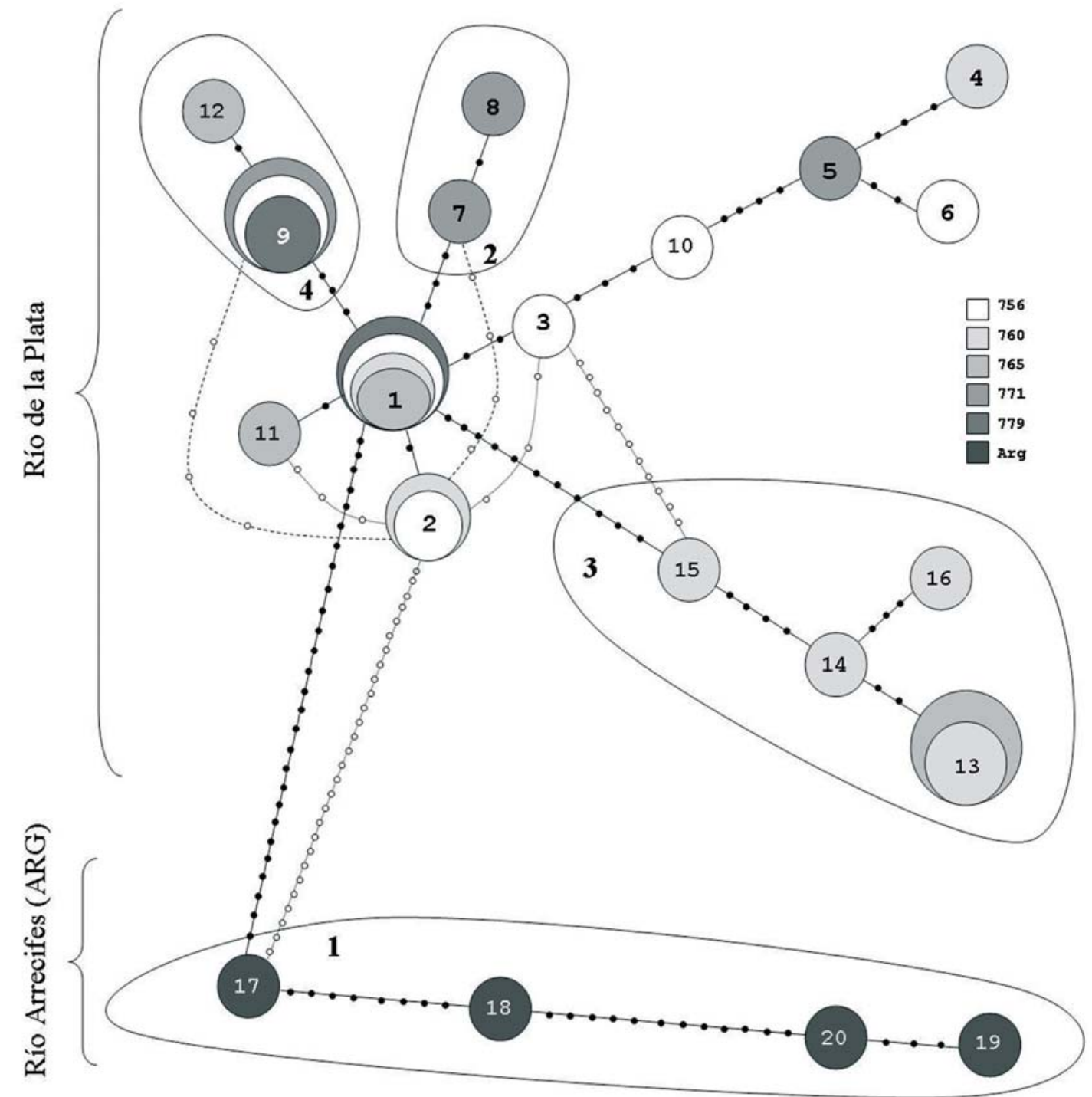

Fig. 4. Minimum spanning network of $P$. albicans haplotypes. The number of mutational steps separating each haplotype were represented by dots. Pointed branches represent alternatives links. The size of the circles represents the frequency of each haplotype. 
(Hardman, 2005, Sullivan et al., 2006). Our results were at odds from those presented by Hardman (2005) in which the Heptapteridae family appears as a basal group in the clade integrated by Pimelodidae and Pseudopimelodidae. In Sullivan et al. (2006) Heptapteridae and Pimelodidae represent sister groups (Fig. 1). Remarkably, the paraphyly of the genus Pimelodus was previously mentioned by Lundberg and Littman (2003).

Pimelodus albicans phylogeographic pattern in the río de la Plata basin. The present work represents the first phylogeographic approach within the genus Pimelodus using mtDNA sequences.

Pimelodus albicans has high levels of genetic variation among cyt b haplotypes in the río de la Plata basin. Genetic divergence of $P$. albicans from different collecting sites revealed low values among río de la Plata localities (range 1\% $-3 \%$ ) and considerable divergence between río Arrecifes and río de la Plata collecting sites $(10 \%)$. Similar values of genetic divergence $(8.3 \%)$ were found among specimens of Rhamdia quelen collected in several rivers of Central and South America representing a sibling species complex (Perdices et al., 2002). The values of nucleotide diversity were higher than those reported in others Asian siluriforms (So et al., 2006).

All the phylogenetic reconstructions showed that $P$. albicans constitutes a monophyletic entity including four well supported monophyletic clades (Fig. 3). In addition, the minimum spanning network tree topology showed the same four assemblages (Fig. 4). Among them, there are two groups formed by samples from the same locality, one group is río Arrecifes (1 in Figs. 3 and 4) and the other one is the 771 collecting site in the río de la Plata (2 in Fig. 3 and 4). The two remaining assemblages included haplotypes from more than one locality. The localities 760 and 765 (3 in Fig.3 and 4) were partially isolated sharing only the haplotype 13 (Fig. 4).

High level of genetic structuring was found in P. albicans by means of AMOVA analyses (Table 4). Under two groups and five groups hypotheses, the percentage of genetic variation $(>70 \%)$ among groups were higher than other alternative ones. Both grouping hypotheses were consistent in showing that río Arrecifes samples constitute an isolated lineage. Moreover, these results were corroborated by the pairwise $\mathrm{F}_{\mathrm{ST}}$ and $\mathrm{Nm}$ values (Table 6) which also considered the río Arrecifes samples isolated from río de la Plata ones. All

Table 6. Population pairwise estimates of $\mathrm{F}_{\mathrm{ST}}$ values (below) and the corresponding indirect estimations of gene flow values (above) found among different collecting sites in Pimelodus albicans. Numbers in bold indicate the significant Fst $P$ values $(\mathrm{a}=0.05)$.

\begin{tabular}{lcrrrrrr}
\hline FSTs $\backslash$ Nm & 1 & 2 & 3 & 4 & 5 & 6 \\
\hline 1: 756 & 0 & 3.7 & 0.8 & 1.6 & 23.3 & 0.1 \\
2: 765 & 0.119 & 0 & 13.3 & 2.1 & 3.9 & 0.2 \\
3: 760 & $\mathbf{0 . 3 9 1}$ & 0.036 & 0 & 0.6 & 0.9 & 0.2 \\
4: 779 & $\mathbf{0 . 2 3 9}$ & 0.190 & $\mathbf{0 . 4 5 5}$ & 0 & 2.4 & 0.1 \\
5: 771 & 0.021 & 0.115 & $\mathbf{0 . 3 6 6}$ & 0.171 & 0 & 0.2 \\
6: río Arrecifes & $\mathbf{0 . 8 1 5}$ & $\mathbf{0 . 7 3 8}$ & $\mathbf{0 . 7 5 4}$ & $\mathbf{0 . 8 2 1}$ & $\mathbf{0 . 7 5 5}$ & 0 \\
\hline
\end{tabular}

present analyses corroborated that río Arrecifes population is the most divergent population within P. albicans data set, representing an unexpected separate lineage. In fact, the genetic divergence $(10 \%)$ between populations of these two regions was similar to those found at intrageneric and intergeneric level in the Pimelodidae data set (Table 2). Based on the present results it is possible to hypothesize that $P$. albicans may be conformed by a sibling species complex as it was previously described for the genus Rhamdia (Perdices et al., 2002).

In all present analyses, the locality 760 was the most partially isolated among río de la Plata collecting sites, although there are no physical barriers separating areas of the estuary. These results support the idea that $P$. albicans has a genetic structure inside the río de la Plata basin. Up to this moment, the isolation of the locality 760 in the río de la Plata is difficult to explain. Temperature, salinity, and seasonal migrations are factors that influence the composition of the fish community from the inner río de la Plata (Jaureguizar et al., 2004). But we did no rule out that P. albicans could migrates for reproduction segregating into different tributaries and generating different schools of haplotypes which could mix in the río de la Plata estuary during a considerable portion of their life cycle. The high nucleotide diversity found in the 765 collecting site (Table 3 ) and the existence of the gene flow with the remaining collecting sites (Table 6) could be concordant with the outlined hypothetic scenarios of the mixing populations in the middle of the río de la Plata estuary. This peculiar reproductive behavior was found in Brachyplatystoma rousseauxii in the Amazon River (Batista \& Alves-Gomes, 2006).

On the other hand, environmental factors such as salinity could influence population structuring in $P$. albicans since low genetic diversity found in the 779 collecting site could be related to the increase of the salinity. This site represent the most distantly station in the río de la Plata estuary toward the border of the Maritime Front (Lasta et al., 2002).

The data presented herein, were partially in agreement with information about population structure found in the congeneric taxa Pimelodus maculatus from the Tietê and Paranapanema Rivers (Brazil). In such study, genetic diversity (GST) and Nm estimate showed that the population from the Tietê River was genetically homogeneous, whereas population structuring was detected in the Paranapanema River (de Almeida et al., 2003). On the other hand, Batista and Alves-Gomes (2006) found non genetic structuring in population of dourada Brachyplatystoma rousseauxii among three collecting sites in the Amazon River. Moreover, low level of genetic differentiation was found in two species of catfish in Cambodian Mekong River by So et al. (2006).

Historical demography and conservation remarks. Tajima's D statistic for all samples rejects the hypothesis of neutral mutation indicating that the total population could be under influence of an expansion process from the ancestral and central haplotype 1 . The star-like network topology could 
support this population demographic scenario in P. albicans. These types of demographic events were also reported in the Asian catfish Pangasius bocourti from Cambodian Mekong River (So et al., 2006).

Taking into account that present analyses detected two different and genetically distantly lineages in P. albicans this results could be suggesting that both phylogroups may represent different Evolution Management Units (Moritz, 1994) in a further conservation program implemented for this species complex.

Further analyses including additional samples from coastal and tributaries rivers of the río de la Plata basin and new data set from nuclear and mitochondrial sequences, could clarify the pattern of the genetic structuring and homing behavior in the populations of $P$. albicans.

\section{Acknowledgments}

We thank the following people: L. Semenas (CRUB, Bariloche), A. Gosztonyi (CENPAT; Puerto Madryn), Sergio Bogan (Museo de La Plata) for samples donation belonging to different Siluriformes species and to Raquel Scorza, Viviana Ramas and Veronica Gutierrez for MS suggestions. The manuscript benefited from the criticisms of two anonymous reviewers. This research received financial support from FREPLATA -PNUD -GEF (2001): "Estudio de diversidad con marcadores genéticos en especies de Clupeiformes y Siluriformes del río de la Plata y su Frente Marítimo" and SECYT MEC UR/PA05-EX1/001 (MEC FPR/F/BI/49/17) projects. The authors are also grateful to the Japanese government for the equipment donation.

\section{Literature Cited}

de Almeida, F. S., L. M. K. Sordé \& E. P. B. Contel. 2003. Population structure analysis of Pimelodus maculatus (Pisces, Siluriformes) from the Tiete and Paranapanema Rivers (Brazil). Genetics and Molecular Biology, 26(3): 301-305.

Batista J. S. \& J. A. Alves-Gomes. 2006. Phylogeography of Brachyplatystoma rousseauxii (Siluriformes - Pimelodidae) in the Amazon Basin offers preliminary evidence for the first case of "homing" for an Amazonian migratory catfish. Genetics and Molecular Research, 5(4): 723-740.

Bockman, F. A. \& G. M. Guazelli. 2003. Family Heptapteridae (Heptapterids). Pp. 406-431. In: Reis, R. E., S. O. Kullander \& C. J. Ferraris Jr (Eds.). Check list of the freshwater fishes of South and Central America. Porto Alegre, Edipucrs, 729p.

Cantatore, P., M. Roberti, G. Pesole, A. Ludovico, F. Milella, M. N. Gasaleta \& C. Saccone. 1994. Evolutionary analysis of cytochrome $b$ sequences in some Perciformes: evidence for a slower rate of evolution than in mammals. Journal of Molecular Evolution, 39(6): 589-597.

Cione, A. L., S. M. Pereira, R. Alonso \& J. Arias. 1985. Los bagres (Osteichthyes: Siluriformes) de la formación Yacoraite (Cretácico tardío) del noroeste argentino. Consideraciones biogeográficas y bioestratigráficas. Ameghiniana, 21(2): 294-304.
Excoffier, L., G. Laval \& S. Schneider. 2005. Arlequin ver. 3.0: an integrated software package for population genetics data analysis. Evolutionary Bioinformatics Online, 1: 47-50.

Excoffier, L., P. E. Smouse \& J. M. Quattro. 1992. Analysis of molecular variance inferred from metric distances among DNA haplotypes: application to human mitochondrial DNA restriction data. Genetics, 131(2): 479-491.

Fink, S. \& W. Fink. 1981. Interrelationships of the ostariophysan fishes (Pisces, Teleostei). Zoological Journal of the Linnean Society, 72: 297-353.

Fu, Y. X. 1997. Statistical test of neutrality of mutations against population growth, hitchhiking and background selection. Genetics, 147(2): 915-925.

García, G., F. Alvarez-Valin \& N. Gomez. 2002. Mitochondrial genes: signals and noise in the phylogenetic reconstruction of the annual killifish genus Cynolebias (Cyprinodontiformes, Rivulidae). Biological Journal of the Linnean Society, 76(1): 49-59

García, G., G. Wlasiuk \& E. P. Lessa. 2000. High levels of mitochondrial cytochrome $b$ divergence in annual killifishes of the genus Cynolebias (Cyprinodontiformes, Rivulidae). Zoological Journal of the Linnean Society, 129(1): 93-110.

Grande, L. \& J. T. Eastman. 1986. A review of Antarctic ichthyofaunas in the light of new fossil discoveries. Palaeontology, 29(1): 113-137.

Hardman, M. 2005. The phylogenetic relationship among nondiplomystid catfishes as inferred from mitochondrial cytochrome b sequences; the search for the ictalurid sister taxon (Otophysi: Siluriformes). Molecular Phylogenetics and Evolution, 37(3): 700-720.

Hasegawa, M., H. Kishino \& T. Yano. 1985. Dating of the humanape splitting by a molecular clock of mitochondrial DNA. Journal of Molecular Evolution, 22(2): 160-174.

Jaureguizar, A. J., R. Menni, R. Guerrero \& C. Lasta. 2004. Environmental factors structuring fish communities of the Río de la Plata estuary. Fisheries Research, 66 (2-3): 195-211.

Kimura, M. 1980. A simple method for estimating evolutionary rate of base substitutions through comparative studies of nucleotide sequences. Journal of Molecular Evolution, 16(2): 111-120.

Kimura, M. \& J. F. Crow. 1964. The number of alleles that can be maintained in a finite population. Genetics, 49(4): 725-738.

Kocher, T. D., W. K. Thomas, A. Meyer, S. V. Edwards, S. Paabo, F. X. Villablanca \& A.C. Wilson. 1989. Dynamics of mitochondrial DNA evolution in animals: amplification and sequencing with conserved primers. Proceedings of the National Academy of Sciences, 86(16): 6196-6200.

Kumar, S., K. Tamura \& M. Nei. 2004. MEGA3: Integrated software for molecular evolutionary genetics analysis and sequence alignment. Briefings in Bioinformatics, 5(2): 150-163.

Lasta C., M. Acha, A. Brazeiro, H. Mianzan, A. Perdomo, M. Gómez \& D. Calliari. 2002. Campaña de Prospección ambiental del Río de la Plata y su Frente Maritimo. 202pp.

Lundberg, J. G., A. H. Bornbusch \& F. Mago-Leccia. 1991a. Gladioglanis conquistador $\mathrm{n}$. sp. from Ecuador with diagnosis of the subfamilies Rhamdiinae Bleeker and Pseudopimelodinae n. subf. (Siluriformes: Pimelodidae). Copeia, 1991: 190-209.

Lundberg, J. G. \& M. W. Littmann. 2003. Family Pimelodidae (Pimelodids). Pp. 432-446. In: Reis R. E., S. O. Kullander and C. J. Ferraris Jr. (Eds). Check list of the freshwater fishes of South and Central America. Porto Alegre, Edipucrs, 729p.

Lundberg, J. G., F. Mago-Leccia \& P. Nass. 1991b. Exallodontus aguanai, a new genus and species of Pimelodidae (Pisces: Silu- 
riformes) from deep river channels of South America and delimitation of the subfamily Pimelodinae. Proceedings of the Biological Society of Washington, 104: 840-869.

Martin, A. P. \& E. Bermingham. 1998. Systematics and evolution of lower Central American cichlids inferred from analysis of cytochrome $b$ gene sequences. Molecular Phylogenetics and Evolution, 9(2): 192-203.

Medrano, J. F., E. Aasen \& L. Sharrow. 1990. DNA extraction from nucleated red blood cells. Biotechniques, 8(1): 43.

Meyer, A., T. D. Kocher, P. Basasibwaki \& A. Wilson. 1990. Monophyletic origin of Lake Victoria fishes suggested by mitochondrial DNA sequences. Nature, 347(6293): 550-553.

Moritz, C. 1994. Applications of mitochondrial DNA analysis in conservation: a critical review. Molecular Ecology, 3(4): 401411.

de Muizon, C., M. Gayet, A. Lavenu, G. Marshall \& B. Sigé. 1983. Late Cretaceous vertebrates including mammals, from Tiupampa, southcentral Bolivia. Geobios, 16(6): 747-753.

Nei, M., 1987. Molecular Evolutionary Genetics. Columbia University Press, New York. 512p.

Palumbi, S., A. Martin, S. Romano, W. O. McMillan, L. Stice \& G. Grabowski. 1991. The simple fool's guide to PCR. Department of Zoology and Kewalo Marine Laboratory, Univ. Hawaii, Honolulu.

Peng, Z., H. Shunping \& Y. Zhang. 2004. Phylogenetic relationships of glyptosteroids fishes (Siluriformes: Sisoridae) inferred from mitochondrial cytochrome b gene sequences. Molecular Phylogenetics and Evolution, 31(3): 979-987.

Perdices, A., E. Bermingham, A. Mantilla \& I. Doadrio. 2002. Evolutionary history of the genus Rhamdia (Teleostei, Pimelodidae) in Central America. Molecular Phylogenetics and Evolution, 25(1): 172-189.

de Pinna, M. C. C. 1998. Phylogenetic relationships of Neotropical Siluriformes (Teleostei: Ostariophysi): historical overview and synthesis of hypotheses. Pp. 279-330. In: L. R. Malabarba, R. E. Reis, R. P. Vari, Z. M. S. Lucena, and C. A. S. Lucena (Eds.). Phylogeny and Classification of Neotropical Fishes. Porto Alegre, Edipucrs, 603p.

Posada, D. \& K. A. Crandall. 1998. Modeltest: testing the model of DNA substitution. Bioinformatics, 14(9): 817-818.

Rannala, B. \& Z. Yang. 1996. Probability distribution of molecular evolutionary trees: a new method of phylogenetic inference. Journal of Molecular Evolution, 43(3): 304-311.

Renesto, E., C. H. Zawadzki \& E. Revaldaves. 2000. Genetic evidence for two species of the genus Pimelodus Lacépède, 1803 (Siluriformes, Pimelodidae) in the Iguaçu River (Brazil). Genetics and Molecular Biology, 23(4): 809-813.

Rodiles-Hernández, R, D. A. Hendrickson, J. G. Lundberg \& J. M. Humphries. 2005. Lacantunia enigmatica (Teleostei: Siluriformes) a new and phylogenetically puzzling freshwater fish from Mesoamerica. Zootaxa, 1000: 1-24
Ronquist, F. \& J. P. Huelsenbeck. 2003. MRBAYES 3: Bayesian phylogenetic inference under mixed models. Bioinformatics, 19(12):1572-1574.

Rozas, J., J. C. Sánchez-DelBarrio, X. Messenguer \& R. Rozas. 2003. DnaSP, DNA polymorphism analyses by the coalescent and other methods. Bioinformatics, 19(18): 2496-2497.

Saitoh, K., M. Miya, J. G. Inoue, N. B. Ishiguro \& M. Nishida. 2003. Mitochondrial Genomics of Ostariophysan Fishes: Perspectives on Phylogeny and Biogeography. Journal of Molecular Evolution, 56(4): 464-472.

Saitou, N. \& M. Nei. 1987. The neighbour-joining method: a new method for reconstructing phylogenetic trees. Molecular Biology and Evolution, 4(4): 406-425.

Shibatta, O. A. 2003. Family Pseudopimelodidae (Bumblebee catfishes, dwarf marbled catfishes). Pp. 401-405. In: Reis R. E., S. O. Kullander \& C. J. Ferraris (Eds). Jr. Check list of the freshwater fishes of South and Central America. Porto Alegre, Edipucrs, 729p.

Shimabukuro-Dias, C. K., C. Oliveira, R. E. Reis \& F. Foresti. 2004. Molecular phylogeny of the armored catfish family Callichthyidae (Ostariophysi, Siluriformes). Molecular Phylogenetics and Evolution, 32(1): 152-163.

Slatkin, M. 1991. Inbreeding corfficients and coalescence times. Genetical Research, 58: 167-175.

So, N., J. K. J. Van Houdt \& F. A. M. Volckaert. 2006. Genetic diversity and population history of the migratory catfishes Pangasianodon hypophthalmus and Pangasius bocourti in the Cambodian Mekong River. Fisheries Science, 72(3): 469-476.

Sullivan, P., J. G. Lundberg \& M. Hardman. 2006. A phylogenetic analysis of the major groups of catfishes (Teleostei: Siluriformes) using rag1 and rag2 nuclear gene sequences. Molecular Phylogenetics and Evolution, 41(3): 636-662.

Sverlij, S., L. López, R. Delfino \& A. Espinach Ros. 1998. Peces del Río Uruguay. C.A.R.U. 89p.

Swofford, D. L. 1998. PAUP*: Phylogenetic Analysis Using Parsimony (*and Other Methods). Version 4.0b8. Sinauer Associates, Sunderland, Massachusetts.

Tajima, F. 1989. Statistical method for testing the neutral mutation hypothesis by DNA polymorphism. Genetics, 123(3): 585595.

Thompson, J. D., T. J. Gibson, F. Plewniak, F. Jeanmougin \& D. G. Hoggins. 1997. The CLUSTAL_X windows interface: flexible strategies for multiple sequence alignment aided by quality analysis tools. Nucleic Acid Research, 25(24): 4876.

Wright, S. 1951. The genetical structure of populations. Annals of Eugenics, 15: 323-354.

Accepted December 2007 Published 31 March 2008 